\title{
Innovative assays to detect bleeding and thrombotic tendencies: a focus on thrombin generation and fibrin formation
}

Citation for published version (APA):

Pelkmans, L. P. J. (2015). Innovative assays to detect bleeding and thrombotic tendencies: a focus on thrombin generation and fibrin formation. [Doctoral Thesis, Maastricht University]. Uitgeverij BOXPress. https://doi.org/10.26481/dis.20151112lp

Document status and date:

Published: 01/01/2015

DOI:

10.26481/dis.20151112lp

Document Version:

Publisher's PDF, also known as Version of record

Please check the document version of this publication:

- A submitted manuscript is the version of the article upon submission and before peer-review. There can be important differences between the submitted version and the official published version of record.

People interested in the research are advised to contact the author for the final version of the publication, or visit the DOI to the publisher's website.

- The final author version and the galley proof are versions of the publication after peer review.

- The final published version features the final layout of the paper including the volume, issue and page numbers.

Link to publication

\footnotetext{
General rights rights.

- You may freely distribute the URL identifying the publication in the public portal. please follow below link for the End User Agreement:

www.umlib.nl/taverne-license

Take down policy

If you believe that this document breaches copyright please contact us at:

repository@maastrichtuniversity.nl

providing details and we will investigate your claim.
}

Copyright and moral rights for the publications made accessible in the public portal are retained by the authors and/or other copyright owners and it is a condition of accessing publications that users recognise and abide by the legal requirements associated with these

- Users may download and print one copy of any publication from the public portal for the purpose of private study or research.

- You may not further distribute the material or use it for any profit-making activity or commercial gain

If the publication is distributed under the terms of Article 25fa of the Dutch Copyright Act, indicated by the "Taverne" license above, 


\section{Nederlandse samenvatting}


In dit proefschrift wordt de ontwikkeling van twee nieuwe testen beschreven die kunnen helpen bij de detectie van verhoogde bloedings- of tromboseneigingen. In hoofdstuk 1 wordt achtergrondinformatie gegeven over hemostase in het algemeen en specifiek over de ziekte van von Willebrand (VWD) en het antifosfolipiden syndroom (APS). VWD wordt onderverdeeld in verschillende subtypen die veelal gebaseerd zijn op kwalitatieve en kwantitatieve defecten van het eiwit von Willebrand factor (VWF). Deze defecten kunnen leiden tot bloedingen die variëren van mild tot zeer ernstig. APS daarentegen leidt tot trombose en/ of zwangerschapscomplicaties. De exacte oorzaak van APS is niet bekend, maar er bestaat een sterke correlatie tussen antilichamen gericht tegen het eiwit beta2-glycoprotein I ( $\beta_{2} \mathrm{GPI}$ ) en het optreden van trombose. Ten slotte worden in hoofdstuk 1 verscheidene technieken besproken die gebruikt worden voor het detecteren van bloedings- en/of tromboseneigingen.

In hoofdstuk 2 wordt verder ingegaan op de structuur en versteviging van een bloedstolsel door de interactie tussen VWF en fibrine te bestuderen. Bij beschadiging van een bloedvat, hechten bloedplaatjes zich met behulp van VWF vast op de plaats van de bloeding om het bloeden te stelpen. Tevens wordt de stollingscascade geactiveerd waardoor uiteindelijk fibrine gevormd wordt door het enzym trombine. Uiteindelijk vormt fibrine een netwerk dat de bloedplaatjes stabiliseert. Voorgaand onderzoek toonde aan dat VWF kan binden aan fibrine, maar de exacte details van deze interactie werden niet beschreven. Wij hebben bevestigd dat VWF interageert met fibrine door gebruik te maken van verschillende technieken die de binding tussen eiwitten meten. Deze interactie tussen VWF en fibrine kan alleen plaatsvinden in de aanwezigheid van trombine. Tevens hebben wij aangetoond dat de interactie van VWF en fibrine de vorming van een fibrinenetwerk niet hindert en bloedplaatjes nog steeds kunnen hechten. Onze bevindingen tonen aan dat fibrine niet alleen een eindproduct van de stollingscascade is, maar ook deelneemt aan de groei van een bloedstolsel.

De hoeveelheid trombine die gevormd wordt, is indicatief voor het risico op bloedingen of trombose. Wanneer in het lichaam teveel trombine geproduceerd wordt, neemt het risico op trombose toe. Te weinig trombine resulteert daarentegen in een verhoogd risico op bloedingen. De hoeveelheid trombine die geproduceerd wordt als het bloed stolt, kan gemeten worden met de trombinegeneratie test of 'Calibrated automated thrombinography (CAT)'. In hoofdstuk 3 hebben we onderzocht of de trombinegeneratie test gevoelig is voor de activatiestatus van VWF met behulp van plasma van VWD type $2 \mathrm{~B}$ patiënten. VWF in het plasma van deze patiënten bindt spontaan aan plaatjesreceptor glycoproteïne Ib, waardoor VWF continu in een geactiveerde status aanwezig is. Door de verlaagde concentraties van FVIII in VWD type 2B patiënten, is de trombinegeneratie in deze patiënten verlaagd. Echter, na toevoeging van bloedplaatjes aan PPP van VWD type 2B patiënten en gezonde vrijwilligers was het verschil in trombinegeneratie veel minder uitgesproken. Door de ratio plaatjes-rijk 
plasma (PRP)/PPP te berekenen voor de trombinegeneratieparameters konden patiënten met type 2B VWD onderscheiden worden van gezonde vrijwilligers. Onze resultaten tonen aan dat trombinegeneratie in PRP gevoelig is voor de activatiestatus van VWF.

In hoofdstuk 4 wordt de relatie onderzocht tussen bloedgroep, trombinegeneratie, protrombine activatie en trombine inactivatie. Door de verlaagde VWF concentratie hebben mensen met bloedgroep $O$ een verhoogde kans op bloedingen. Ons onderzoek toont aan dat trombinegeneratie, zowel in PRP als PPP, 10\% lager is in personen met bloedgroep O. Dit kan verklaard worden door een verlaagde omzetting van protrombine in trombine. Daarnaast is de inactivatie van trombine verlaagd, met een significant grotere rol voor de trombineremmer $a_{2}$-macroglobuline ten opzichte van antitrombine. Deverlaging in trombinegeneratie is onafhankelijk van bloedplaatjes aangezien de trombinegeneratie in gelijke mate verlaagd is in PPP en PRP. Door de verlaagde concentraties van VWF in personen met bloedgroep $\mathrm{O}$, zijn ook de FVIII niveaus verminderd, wat bijdraagt tot de lagere trombinegeneratie.

De ideale test die bloedings- en tromboseneigingen kan voorspellen bestaat op dit moment niet. De huidige testen meten ofwel de vorming van fibrine ofwel de vorming van trombine, terwijl aangetoond werd dat deze testen niet altijd overeenkomen. Bovendien meten de huidige testen onder statische condities, terwijl bewezen werd dat de fysiologische stroming van het bloed een significante invloed heeft op de activiteit van verschillende eiwitten, aanhechting van cellen, fibrinevorming, enz. Daarom hebben wij een methode ontwikkeld die tegelijkertijd de vorming van trombine en fibrine meet onder fysiologische stromingscondities. De technische en klinische validatie van deze methode wordt besproken in hoofdstuk 5. In onze methode maken we gebruik van een kegel en plaat rheometer waarin een fluorescentiemeter werd ingebouwd. Gebruik makende van deze methode hebben wij aangetoond dat een verhoogde stromingssnelheid resulteert in een verlaagde trombinegeneratie en fibrineformatie. Daarnaast leidden verhoogde concentraties van fibrinogeen tot een dosisafhankelijke stijging van de fibrinevorming. Onze methode werd klinisch gevalideerd in patiënten die een cardio-thoracale operatie ondergingen. De fibrinevorming gemeten met de rheometer correleerde met de fibrinogeenconcentratie in het monster, en rotationele tromboelastometrie (ROTEM), de standaardtechniek die gebruikt wordt om de sterkte van een bloedstolsel te bepalen. Trombinegeneratieparameters correleerden tevens met de volbloed CAT parameters. Een belangrijke bevinding is dat onze rheometer-gebaseerde methode indicatief was voor de hoeveelheid bloedverlies tijdens/na een cardio-thoracale operatie. 
Baby's en kinderen hebben een significant lagere kans op trombose in vergelijking met volwassen. Voorheen werd nooit onderzoek verricht naar de vorming en structuur van bloedstolsels in baby's en kinderen. In hoofdstuk 6 hebben we de processen van trombinegeneratie, fibrinevorming en fibrinolysevergeleken tussen kinderen en volwassenen. Uit dit onderzoek bleek dat de jongere populaties een verlaagde trombinegeneratie hebben, alsook een verminderde fibrinevorming in vergelijking met volwassenen. Daarnaast werden de bloedstolsels van de kinderen gekenmerkt door grotere poriën, wat resulteert in een verminderde weerstand tegen fibrinolyse. Toevoeging van 'tissue plasminogen activator' (tPA) resulteerde in een significante afname van de grootte van de poriën in baby's en kinderen, maar niet in volwassenen. Dit alles toont aan dat zowel de bloedstolselvorming en -structuur, als de reactie op het toedienen van trombolytische medicatie verschillend is in baby's en kinderen ten opzichte van volwassenen.

Hoofdstuk 7 licht de problemen toe die zich voordoen bij de diagnose van APS. Het veelvuldig voorkomen van de klinische symptomen trombose en zwangerschapscomplicaties onafhankelijk van APS, en de grote variabiliteit in resultaten tussen verschillende diagnostische testen, resulteert in een hoge kans op vals positieve resultaten. Een van de testen die gebruikt worden voor de diagnose meet de aanwezigheid van antistoffen tegen $\beta_{2}$ GPI, de zogenaamde anti- $\beta_{2}$ GPI ELISA. Wij hebben eerder aangetoond dat antistoffen gericht tegen epitoop G40-R43 van domein I van $\beta_{2}$ GPI pathogeen zijn, gezien hun hoge correlatie met trombose. Deze associatie met trombose werd tot nu toe niet aangetoond voor antistoffen gericht tegen andere epitopen. Desalniettemin, blijft de vraag bestaan of enkel deze anti-domein I antistoffen belangrijk zijn voor de diagnose van APS.

In hoofdstuk 8 onderzochten wij vervolgens of de hoge variabiliteit in testresultaten tussen verschillende anti- $\beta_{2}$ GPI ELISA's verklaard kan worden door een suboptimale toegankelijkheid van het pathogene $\beta_{2}$ GPI epitoop G40-R43. Het gebruik van twee monoklonale antilichamen die een domein I epitoop herkennen onafhankelijk van de conformatie versus enkel in de open conformatie, maakt het mogelijk om een onderscheid te maken tussen open en gesloten $\beta_{2}$ GPI. Vijf commercieel verkrijgbare ELISA's werden onderzocht met behulp van deze antilichamen en slechts in één test was alle $\beta_{2}$ GPI aanwezig in de open vorm. In de resterende testen was een deel van $\beta_{2}$ GPI aanwezig in een gesloten vorm waardoor epitoop G40-R43 minder toegankelijk is. Om de gevolgen in te schatten voor de diagnose, werden plasmastalen van APS patiënten getest op twee verschillende ELISA's, waarvan eén gekenmerkt werd door een verlaagde toegankelijkheid van epitoop G40-R43, terwijl in de andere ELISA alle $\beta_{2}$ GPI aanwezig is in de open vorm. Onze resultaten toonden aan dat een verminderde toegankelijkheid van epitoop G40-R43 leidt tot een vals negatieve classificatie van APS patiënten. 
In het addendum van hoofdstuk 8 wordt de ontwikkeling van een nieuwe diagnostische test voor APS beschreven. Onze op trombinegeneratie gebaseerde test is, in tegenstelling tot de veelgebruikte ELISA's, een functionele test waardoor het risico op vals negatieve en vals positieve resultaten vermindert. Onze test is gevoelig voor een antilichaam dat specifiek bindt aan het pathogene epitoop G40-R43. Hoewel de preliminaire resultaten veelbelovend zijn, moet de test verder gevalideerd worden op een grote patiëntenpopulatie.

De inhoud van het proefschrift wordt samengevat en bediscussieerd in hoofdstuk 9. In dit proefschrift is nieuwe kennis beschreven over de binding van VWF aan fibrine en de gevolgen voor de binding van bloedplaatjes. Tevens is vastgesteld dat stromingscondities van belang zijn bij het meten van stollingspotentie en dat het belangrijk is om de problemen bij de diagnose van APS te begrijpen. De opgedane kennis hebben we toegepast bij de ontwikkeling van onze nieuwe testen. De resultaten van beide testen zijn veelbelovend, maar moeten nog verder gevalideerd worden in grote patiëntenpopulaties. Daarnaast worden in dit hoofdstuk de eigenschappen beschreven die een ideale hemostasis- en stollingstest zou moeten hebben. Er wordt afgesloten met het feit dat het belangrijk is om een goed begrip te hebben van de essentiële moleculaire interacties voordat een optimale test ontwikkeld kan worden. 